\title{
Pyrazole Synthesis under Microwave Irradiation and Solvent-free Conditions
}

\author{
Lilian Buriol, Clarissa P. Frizzo, Mara R. B. Marzari, Dayse N. Moreira, \\ Liziê D. T. Prola, Nilo Zanatta, Helio G. Bonacorso and Marcos A. P. Martins * \\ Núcleo de Química de Heterociclos, Departamento de Química, \\ Universidade Federal de Santa Maria, 97105-900 Santa Maria-RS, Brazil
}

\begin{abstract}
Este trabalho descreve a síntese de 4,5-diidro- $1 H$-pirazóis pela reação de ciclocondensação de hidrazinas $\left[\mathrm{NH}_{2} \mathrm{NH}-\mathrm{R}^{2}\right.$, onde $\left.\mathrm{R}^{2}=\mathrm{CO}_{2} \mathrm{Me}, \mathrm{Ph}, \mathrm{CH}_{2} \mathrm{CH}_{2} \mathrm{OH}\right]$ com 4-alcóxi-1,1,1-trifluor-3-alquen2-onas $\left[\mathrm{CF}_{3} \mathrm{C}(\mathrm{O}) \mathrm{CH}=\mathrm{C}\left(\mathrm{R}^{1}\right) \mathrm{OR}\right.$, onde $\mathrm{R} / \mathrm{R}^{1}=\mathrm{Et} / \mathrm{H}, \mathrm{Me} / \mathrm{Me}$ and $\left.\mathrm{Me} / \mathrm{Ph}\right]$ sob irradiação de microondas utilizando um equipamento de micro-ondas para síntese e em condição livre de solvente. Algumas reações foram realizadas na presença de metanol. Os resultados obtidos utilizando micro-ondas para síntese foram comparados com aqueles obtidos quando a reação foi feita pelo método convencional e no forno de micro-ondas doméstico. Os produtos foram obtidos com bons rendimentos em um intervalo de tempo pequeno. Além disso, foi demonstrado que a temperatura da reação alterou a formação dos produtos para cada hidrazina mostrando que o equipamento de micro-ondas para síntese é eficiente para as reações de hidrazinas com 4-alcóxi-1,1,1-trifluor-3alquen-2-onas levando à formação dos produtos 4,5-diidro- $1 H$-pirazóis e pirazóis.
\end{abstract}

This paper presents a study of solvent-free reaction conditions using microwave irradiation (MW) to obtain 4,5-dihydro-1 $H$-pyrazoles and dehydrated pyrazoles by the cyclocondensation reaction of 4-alkoxy-1,1,1-trifluoro-3-alken-2-ones $\left[\mathrm{CF}_{3} \mathrm{C}(\mathrm{O}) \mathrm{CH}=\mathrm{C}\left(\mathrm{R}^{1}\right) \mathrm{OR}\right.$, where $\mathrm{R} / \mathrm{R}^{1}=\mathrm{Et} / \mathrm{H}$, $\mathrm{Me} / \mathrm{Me}$ and $\mathrm{Me} / \mathrm{Ph}]$ with hydrazines $\left[\mathrm{NH}_{2} \mathrm{NH}-\mathrm{R}^{2}\right.$, where $\left.\mathrm{R}^{2}=\mathrm{CO}_{2} \mathrm{Me}, \mathrm{Ph}, \mathrm{CH}_{2} \mathrm{CH}_{2} \mathrm{OH}\right]$. Some reactions were performed under the same reaction conditions using methanol as solvent. The results obtained using MW equipment for synthesis under solvent-free conditions were also compared with those described in literature for conventional thermal heating and heating with a domestic MW oven. In general, the products furnished by reaction in MW equipment for synthesis presented better yields and shorter reaction times. In addition, it was demonstrated that the reaction temperature altered the formation of products for each hydrazine showing that MW equipment for synthesis is efficient for reacting hydrazines and 4-alkoxy-1,1,1-trifluoro-3-alken-2-ones to procedure the products 4,5-dihydro- $1 H$-pyrazoles and dehydrated pyrazoles.

Keywords: microwave irradiation, solvent-free, pyrazoles, cyclocondensation reactions

\section{Introduction}

Sustainability is an increasingly important issue in the wider context of population, health, the environment, energy, technology, renewable resources, and, in the sciences, as an integral part of the rapidly emerging field called Green Chemistry. ${ }^{1-3}$ Removing organic solvents in chemical synthesis is important in the drive towards benign chemical technologies. In this context, the use of microwave-assisted organic synthesis (MAOS) has emerged as an alternative and efficient tool, especially in heterocyclic synthesis. ${ }^{4}$ Many reviews have been published recently that

*e-mail: mmartins@base.ufsm.br detail the utility of MAOS, however the exact reasons why microwave (MW) heating enhances chemical processes are still unknown. ${ }^{5-10}$

Although reports of procedures that use domestic MW ovens can be found in the literature, their lack of control systems presents a serious drawback. In general, it is not possible to determine the reaction temperature in an accurate way. Additionally, performing chemical synthesis in domestic MW ovens can be troublesome because of the lack of a pressure control and of a means of stirring the reaction mixture. Furthermore, the pulsed irradiation resulting from having no homogeneous microwave field may lead to problems of reproducibility. Another concern is safety. Heating organic solvents in open vessels in a microwave oven can lead to violent explosions induced by 
electric arcs inside the cavity or sparking resulting from the switching of magnetrons. ${ }^{10}$

Recent improvements in controlling reactions have been made possible by MW equipment for synthesis. These equipments have new tools, such as simultaneous external cooling of the reaction mixture (maintaining below room temperature), in this case, the reaction vessel is cooled from the outside by compressed air or with the aid of a cooling fluid while being irradiated by microwaves. ${ }^{11,12}$ This allows a higher level of microwave power to be directly administered to the reaction mixture but will prevent overheating by continuously removing heat. ${ }^{11,12}$ According to some studies, transformations of this type involving polar intermediates or transition states are likely to be accelerated by microwave irradiation due to a specific interaction of the electric field with the polar reaction species, which is not connected to the reaction temperature. ${ }^{9}$

Reactions performed in microwave ovens must be considered in relation to the reaction medium. Solvent effects are of especially great importance. If polar solvents are involved, either aprotic (e.g. DMF) or protic (e.g. alcohols), the main absorption occurs between the microwaves and the polar molecules of the solvent. In this case, energy transfer is from the solvent to the reaction mixtures and reactants. Consequently, the results should be nearly the same as under classic heating. The absence of MW effects was demonstrated by several experiments carefully carried out in DMF. ${ }^{13}$ More interesting may be the use of nonpolar solvents (e.g. xylene, toluene, hydrocarbons) as there is only a very weak solvent-MW interaction (they can be considered transparent solvents). By far, the best situation is that of solvent-free reactions, where the absorption of microwave irradiation should be limited only to the reacting species. ${ }^{14}$

Several methods for the pyrazole scaffold have been described in literature, including MW assisted methods..$^{15-17}$ 4,5-Dihydro- $1 H$-pyrazoles are important nitrogen-containing five-membered heterocyclic compounds, with applications as analytical reactants and agrochemicals, ${ }^{18}$ besides possessing important pharmacological activities such as antitumor ${ }^{19}$ and anti-inflammatory. ${ }^{20}$ Our research group has worked with cyclocondensation reactions to obtain pyrazoles in both domestic MW ovens and MW equipment for synthesis. ${ }^{21}$ Thus, the aims of this work are: (i) to investigate the use of microwave irradiation to promote and accelerate the cyclocondensation reaction between enones (4-alkoxy1,1,1-trifluoro-3-alken-2-one) and three hydrazines in MW equipment for synthesis; (ii) to determinate the reaction conditions to obtain 4,5-dihydro- $1 H$-pyrazoles and dehydrated pyrazoles in MW for synthesis under solventfree conditions and in $\mathrm{MeOH}$; (iii) to compare the reaction conditions with the results obtained under conventional thermal heating and domestic MW oven in order to evaluate the effect of the MW equipment for synthesis in these reactions (Scheme 1).

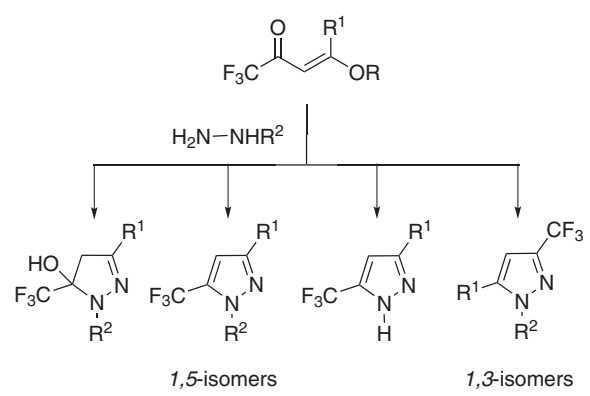

$\mathrm{R} / \mathrm{R}^{1}=\mathrm{Et} / \mathrm{H}, \mathrm{Me} / \mathrm{Me}, \mathrm{Me} / \mathrm{Ph}$ $\mathrm{R}^{2}=\mathrm{CO}_{2} \mathrm{Me}, \mathrm{Ph}, \mathrm{CH}_{2} \mathrm{CH}_{2} \mathrm{OH}$

Scheme 1.

\section{Results and Discussion}

In order to evaluate the cyclocondensation reaction conditions to obtain 4,5-dihydro- $1 \mathrm{H}$-pyrazoles or pyrazoles from the reaction of enones and hydrazines using MW equipment for synthesis, a series of experiments was performed. These experiments were organized into three groups and in each group, three enones 1a-c were reacted with hydrazines $\mathbf{2}, \mathbf{5}$ and $\mathbf{9}$ under solvent-free conditions (Schemes 2, 3 and 4).

The first experiment evaluated the reaction of enones 1a-c with methyl hydrazinocarboxylate $\mathbf{2}$, which furnished the 4,5-dihydro- $1 H$-pyrazoles 3a-c or the dehydrated products 4a-c. In accordance with Scheme 2, it is possible to assert that product $\mathbf{3 b}$ was the least stable 4,5-dihydro- $1 H$ pyrazole, undergoing partial loss of the methyl carboxylate group at $150^{\circ} \mathrm{C}$ and total loss at $200^{\circ} \mathrm{C}$. 4,5-Dihydro- $1 \mathrm{H}$ pyrazole $\mathbf{3 a}$ was slightly more stable than $\mathbf{3 b}$, undergoing total loss of the methyl carboxylate group at $200{ }^{\circ} \mathrm{C}$, followed by 4,5 -dihydro- $1 \mathrm{H}$-pyrazole $\mathbf{3 c}$, the most stable, undergoing partial loss of the methyl carboxylate group at $200{ }^{\circ} \mathrm{C}$ for $6 \mathrm{~min}$ and total loss at $200{ }^{\circ} \mathrm{C}$ for $12 \mathrm{~min}$. From the results, it was possible to presume that for methyl hydrazinocarboxylate, 4,5-dihydro- $1 H$-pyrazole was obtained in mild temperatures and the $\mathrm{N} H$-pyrazole was formed at more drastic temperature conditions.

Many studies have shown that the presence of the trifluoromethyl group is one of the most important factors in the stability of 4,5-dihydro- $1 H$-pyrazoles. ${ }^{22}$ Thus, we found it extremely important to investigate the possibility of dehydrating 4,5-dihydro- $1 \mathrm{H}$-pyrazoles to obtain the aromatic 1-carboxymethyl-5-trifluoromethylpyrazole- $1 \mathrm{H}$ pyrazoles. However, in this case, the expected aromatic 


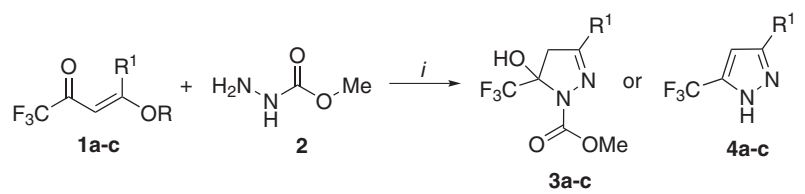

i: Solvent-free, MW

\begin{tabular}{lccccccc}
\hline Enone & $\mathrm{R}$ & $\mathrm{R}^{1}$ & $\begin{array}{c}\mathrm{T} \\
\left({ }^{\circ} \mathrm{C}\right)\end{array}$ & $\begin{array}{c}\text { time } \\
(\mathrm{min})\end{array}$ & Product(s) & $\begin{array}{c}\text { Molar } \\
\text { ratio 3:4 }\end{array}$ & $\begin{array}{c}\mathrm{Yield}^{\mathrm{a}} \\
(\%)\end{array}$ \\
\hline 1a & $\mathrm{Et}$ & $\mathrm{H}$ & 50 & 8 & $\mathbf{3 a}$ & - & 70 \\
1a & $\mathrm{Et}$ & $\mathrm{H}$ & 100 & 8 & $\mathbf{3 a}$ & - & 73 \\
1a & $\mathrm{Et}$ & $\mathrm{H}$ & 150 & 8 & $\mathbf{3 a}$ & - & 78 \\
1a & $\mathrm{Et}$ & $\mathrm{H}$ & 200 & 8 & $\mathbf{4 a}$ & - & 74 \\
1b & $\mathrm{Me}$ & $\mathrm{Me}$ & 50 & 6 & $\mathbf{3 b}$ & - & 62 \\
1b & $\mathrm{Me}$ & $\mathrm{Me}$ & 100 & 6 & $\mathbf{3 b}$ & - & 90 \\
1b & $\mathrm{Me}$ & $\mathrm{Me}$ & 150 & 6 & $\mathbf{3 b}: 4 \mathbf{b}$ & $3: 1$ & 81 \\
1b & $\mathrm{Me}$ & $\mathrm{Me}$ & 200 & 6 & $\mathbf{4 b}$ & - & 80 \\
1c & $\mathrm{Me}$ & $\mathrm{Ph}$ & 50 & 6 & $\mathbf{3 c}$ & - & 80 \\
1c & $\mathrm{Me}$ & $\mathrm{Ph}$ & 100 & 6 & $\mathbf{3 c}$ & - & 82 \\
1c & $\mathrm{Me}$ & $\mathrm{Ph}$ & 150 & 6 & $\mathbf{3 c}$ & - & 71 \\
1c & $\mathrm{Me}$ & $\mathrm{Ph}$ & 200 & 6 & $\mathbf{3 c : 4 c}$ & $1: 1$ & 80 \\
1c & $\mathrm{Me}$ & $\mathrm{Ph}$ & 200 & 12 & $\mathbf{4 c}$ & - & 94 \\
\hline
\end{tabular}

${ }^{\text {a } Y i e l d ~ o f ~ i s o l a t e d ~ p r o d u c t s . ~}$

Scheme 2.

product was not formed, but rather the $\mathrm{NH}$-pyrazole due to loss of the carboxylate group. Product $\mathbf{4} \mathbf{c}$ was obtained only after 12 min of irradiation at $200{ }^{\circ} \mathrm{C}$, which demonstrates that the dehydratation reaction under MW conditions was susceptible to the substituent effect, showing that the phenyl substituent stabilized the 1-carboxymethyl-4,5-dihydro5 -trifluoromethyl- $1 \mathrm{H}$-pyrazoles. This failure to obtain dehydrated pyrazoles was a surprise, because in previous studies ${ }^{23}$ we obtained similar trihalomethylated 4,5-dihydro$1 \mathrm{H}$-pyrazoles containing a strong electron-withdrawing group attached to the N1-atom, where it was possible to eliminate a water molecule and obtain the aromatic pyrazole without the loss of the N1-group, by stirring the reaction mixture in sulfuric acid, for $8 \mathrm{~h}$, at $25^{\circ} \mathrm{C}$. However, we have also observed that some 4,5-dihydro$1 H$-pyrazoles with an electron-withdrawing group attached to the N1-atom undergo dehydration when heated with a simultaneous loss of the carboxylate group, leading to the formation of 5-trifluoromethyl- $1 H$-pyrazole. ${ }^{24}$

The second experiment evaluated the reaction of enones 1a-c with phenylhydrazine 5 , which furnished the 1-phenyl4,5-dihydro- $1 H$-pyrazoles 6a-c or dehydrated products 7a-c and 8a-b in mild temperature conditions. The results are summarized in Scheme 3. The results demonstrate that due to the higher reactivity of phenylhydrazine $\mathbf{5}$ in comparison with methyl hydrazinocarboxylate $\mathbf{2}$, lower temperatures and shorter reaction times were required to obtain the products and an isomeric mixture (1,5-isomer and 1,3-isomer) was formed in the case of enones 1a and $\mathbf{1 b}$. In addition, the $\mathrm{NH}$-pyrazole was not isolated in any of the experiments when enones 1a-c reacted with phenylhydrazine $\mathbf{5}$.

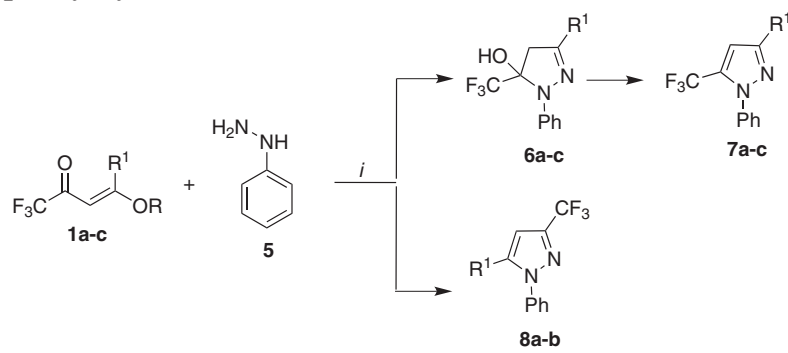

i: Solvent-free, MW

\begin{tabular}{lccccccc}
\hline Enone & $\mathrm{R}$ & $\mathrm{R}^{1}$ & $\begin{array}{c}\mathrm{T} \\
\left({ }^{\circ} \mathrm{C}\right)\end{array}$ & $\begin{array}{c}\text { time } \\
(\mathrm{min})\end{array}$ & Product(s) ${ }^{\mathrm{a}}$ & $\begin{array}{c}\text { Molar } \\
\text { ratio }\end{array}$ & $\begin{array}{c}\text { Yield }^{\mathrm{b}} \\
(\%)\end{array}$ \\
\hline $\mathbf{1 a}$ & $\mathrm{Et}$ & $\mathrm{H}$ & 50 & 6 & $\mathbf{6 a}$ & - & 74 \\
$\mathbf{1 a}$ & $\mathrm{Et}$ & $\mathrm{H}$ & 100 & 6 & $\mathbf{6 a}$ & - & 84 \\
$\mathbf{1 a}$ & $\mathrm{Et}$ & $\mathrm{H}$ & 150 & 6 & $\mathbf{7 a : 8 a}$ & $1: 5$ & 75 \\
$\mathbf{1 a}$ & $\mathrm{Et}$ & $\mathrm{H}$ & 200 & 6 & $\mathbf{7 a : 8 a}$ & $1: 2.5$ & 88 \\
$\mathbf{1 b}$ & $\mathrm{Me}$ & $\mathrm{Me}$ & 50 & 1 & $\mathbf{6 b}$ & - & 95 \\
$\mathbf{1 b}$ & $\mathrm{Me}$ & $\mathrm{Me}$ & 100 & 6 & $\mathbf{6 b}: \mathbf{7 b}: 8 b$ & $5: 10: 3$ & 93 \\
$\mathbf{1 b}$ & $\mathrm{Me}$ & $\mathrm{Me}$ & 150 & 6 & $\mathbf{7 b : 8 b}$ & $3: 1$ & 92 \\
$\mathbf{1 b}$ & $\mathrm{Me}$ & $\mathrm{Me}$ & 200 & 6 & $\mathbf{7 b : 8 b}$ & $3: 1$ & 82 \\
$\mathbf{1 c}$ & $\mathrm{Me}$ & $\mathrm{Ph}$ & 50 & 6 & $\mathbf{6 c}$ & - & 93 \\
$\mathbf{1 c}$ & $\mathrm{Me}$ & $\mathrm{Ph}$ & 100 & 6 & $\mathbf{6 c : 7 c}$ & $1: 5$ & 70 \\
$\mathbf{1 c}$ & $\mathrm{Me}$ & $\mathrm{Ph}$ & 150 & 6 & $\mathbf{7 c}$ & - & 90 \\
$\mathbf{1 c}$ & $\mathrm{Me}$ & $\mathrm{Ph}$ & 200 & 6 & $\mathbf{7 c}$ & - & 82 \\
\hline
\end{tabular}

${ }^{\mathrm{a}}$ Isomer ratio was determined by ${ }^{1} \mathrm{H}$ NMR. The formation of 1,3 - and 1,5-isomers was determined by comparison with literature date. ${ }^{26,27}$ bYield of isolated products.

Scheme 3.

In previous works, our research group demonstrated that the reaction of phenylhydrazine $\mathbf{5}$ with enone $\mathbf{1 b}$, under conventional thermal heating (ethanol reflux, during $4 \mathrm{~h}$ ) resulted in product $\mathbf{6 b}$ and the attempt to obtain 5-trifluoromethyl-1-phenyl-1 $H$-pyrazoles by dehydration of compound 6a with sulfuric acid was unsuccessful. ${ }^{25}$ Our research group has also demonstrated that these reactions, when performed in a domestic MW oven, led to formation of 4,5-dihydro- $1 H$-pyrazoles from which it was possible to obtain a dehydrated product. ${ }^{26}$ Therefore, although the formation of 6a-c was probably due to the electronic conjugation between the $\pi$-system of the phenyl group and the lone pair of electrons of the nitrogen atom (N1) of the pyrazoline-ring, which makes the aromatization of the pyrazole-ring more difficult, in the domestic MW oven the reaction of phenylhydrazine with enones resulted in 
dehydrated products. ${ }^{26}$ The reaction of phenylhydrazine $\mathbf{5}$ with enone 1a resulted in a mixture of products $6 \mathbf{a}$ and $7 \mathbf{a}$; and with enone $\mathbf{1 b}$ it resulted in a mixture of products $\mathbf{7 b}$ and $\mathbf{8 b}$; while the reaction of phenylhydrazine with enone $1 \mathbf{c}$ did not produce $7 \mathbf{c} .^{26}$ These results showed the efficiency of MW equipment for synthesis when compared with domestic MW oven. With MW equipment for synthesis, the products 4,5-dihydro- $1 H$-pyrazole $\mathbf{6 a}$ and pyrazoles $7 \mathbf{a}$ and $\mathbf{8 a}$, were obtained separated from enone $\mathbf{1 a}$. In addition, the 1,5-diphenyl-pyrazole $\mathbf{7 c}$ from enone $\mathbf{1} \mathbf{c}$ was isolated for the first time.

The cyclocondensation reaction of enones 1a-c with 2-hydroxyethylhydrazine $\mathbf{9}$ demonstrated once again the difference in the reactivity of hydrazines $\mathbf{2}, \mathbf{5}$ and $\mathbf{9}$. The results are summarized in Scheme 4. As was expected, 1-alkyl-4,5-dihydro- $1 H$-pyrazoles were not isolated due to the reactivity of hydrazine and the lower stability of this compound. All enones, under all microwave reaction conditions evaluated, resulted in pyrazoles 10a-c and 11a-c. Enone 1a was reacted with 2-hydroxyethylhydrazine 9, under microwave irradiation, at $50{ }^{\circ} \mathrm{C}$ for 2 min furnishing only product 11a. The presence and the ratio of isomers $\mathbf{1 0}$ (1,5-isomer) and $\mathbf{1 1}$ (1,3-isomer) were verified using the ${ }^{1} \mathrm{H}$ and ${ }^{13} \mathrm{C}$ NMR spectra and mass spectrometric fragmentation.

The initial results also showed a difference in reactivity among the hydrazines, which increased in the order: methyl hydrazinocarboxylate $\mathbf{2}$, phenylhydrazine $\mathbf{5}$, and 2-hydroxylethylhydrazine $\mathbf{9}$. This difference in reactivity was also evidenced by the fact that the substituent attached at the $\mathrm{N}$-atom was required in order to obtain the products. When the substituent was an electron-withdrawing group, such as methyl carboxylate, the nucleophilicity of the $\mathrm{N}$-atom decreased, while with an electron-donating group, such as hydroxyethyl, the nucleophilicity of the $\mathrm{N}$-atom increased. In addition, it was possible to observe the important influence of the reaction temperature in the obtainment of the 4,5-dihydro- $1 H$-pyrazoles or pyrazoles, with $100{ }^{\circ} \mathrm{C}$ of variation in the reaction temperature. Reactions performed using hydrazine $\mathbf{2}$ showed that the 4,5-dihydro- $1 H$-pyrazoles were the most stable products and the dehydrated pyrazole was not obtained, while the $\mathrm{NH}$-pyrazole was obtained from the loss of the carboxylate group. When $\mathbf{5}$ was reacted with 1a-c, the intermediate 1-phenyl-4,5-dihydro- $1 H$-pyrazole was formed at a lower temperature in comparison with the reaction of $\mathbf{1 a - c}$ with $\mathbf{2}$. In this context, the hydrazine $\mathbf{9}$, which is the most reactive hydrazine, reacted with enones 1a-c resulting in pyrazoles at very low temperatures and short reaction times. The data from the reactions between enones $\mathbf{1 a - c}$ and hydrazines $\mathbf{2}$, 5 and $\mathbf{9}$ are shown in Table 1.

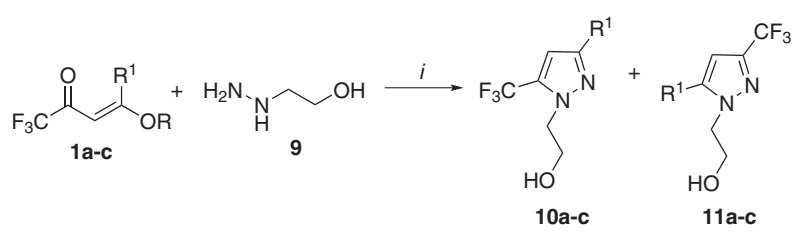

i: Solvent-free, MW

\begin{tabular}{|c|c|c|c|c|c|c|c|}
\hline Enone & $\mathrm{R}$ & $\mathrm{R}^{1}$ & $\begin{array}{c}\mathrm{T} \\
\left({ }^{\circ} \mathrm{C}\right) \\
\end{array}$ & $\begin{array}{l}\text { time } \\
(\min )\end{array}$ & $\operatorname{Product}(\mathrm{s})^{\mathrm{a}}$ & $\begin{array}{c}\text { Molar } \\
\text { ratio }\end{array}$ & $\begin{array}{c}\text { Yield }^{\mathrm{b}} \\
(\%)\end{array}$ \\
\hline $1 \mathbf{a}$ & Et & $\mathrm{H}$ & 50 & 2 & $11 a$ & - & 75 \\
\hline $1 a$ & Et & $\mathrm{H}$ & 50 & 6 & 10a:11a & $1: 10$ & 74 \\
\hline $1 \mathbf{a}$ & Et & $\mathrm{H}$ & 100 & 6 & 10a:11a & $1: 10$ & 83 \\
\hline $1 \mathrm{a}$ & Et & $\mathrm{H}$ & 150 & 6 & 10a:11a & $1: 1.3$ & 67 \\
\hline $1 \mathbf{a}$ & Et & $\mathrm{H}$ & 200 & 6 & 10a:11a & $1.5: 1$ & 79 \\
\hline $1 b$ & $\mathrm{Me}$ & $\mathrm{Me}$ & 50 & 1 & 10b:11b & $1: 5$ & 74 \\
\hline $1 b$ & $\mathrm{Me}$ & $\mathrm{Me}$ & 50 & 6 & 10b:11b & $1: 10$ & 78 \\
\hline $1 b$ & $\mathrm{Me}$ & $\mathrm{Me}$ & 100 & 6 & 10b:11b & $1: 5$ & 72 \\
\hline $1 b$ & $\mathrm{Me}$ & $\mathrm{Me}$ & 150 & 6 & $10 b: 11 b$ & $1: 1.4$ & 76 \\
\hline $1 b$ & $\mathrm{Me}$ & $\mathrm{Me}$ & 200 & 6 & 10b:11b & $1: 1.4$ & 70 \\
\hline $1 c$ & $\mathrm{Me}$ & $\mathrm{Ph}$ & 50 & 6 & 10c:11c & $1: 1$ & 73 \\
\hline $1 c$ & $\mathrm{Me}$ & $\mathrm{Ph}$ & 100 & 6 & 10c:11c & $1: 1$ & 75 \\
\hline $1 c$ & $\mathrm{Me}$ & $\mathrm{Ph}$ & 150 & 6 & 10c:11c & $3: 1$ & 80 \\
\hline $1 c$ & $\mathrm{Me}$ & $\mathrm{Ph}$ & 200 & 6 & 10c:11c & $3: 1$ & 64 \\
\hline
\end{tabular}

Scheme 4.

Table 1. Comparison of the reaction conditions between hydrazines $\mathbf{2}, \mathbf{5}$, 9 and enones 1a-c under microwave irradiation

\begin{tabular}{lcccc}
\hline Hydrazine & Products & $\begin{array}{c}\mathrm{T} \\
\left({ }^{\circ} \mathrm{C}\right)\end{array}$ & $\begin{array}{c}\text { time } \\
(\mathrm{min})\end{array}$ & $\begin{array}{c}\text { Yields }^{\mathrm{a}} \\
(\%)\end{array}$ \\
\hline $\mathrm{H}_{2} \mathrm{NNHCO}_{2} \mathrm{Me} \mathrm{2}$ & 3a-c & 50 & $6-8$ & $73-98$ \\
$\mathrm{H}_{2} \mathrm{NNHCO}_{2} \mathrm{Me} \mathrm{2}$ & $\mathbf{4 a - c}$ & 200 & $6-12$ & $74-94$ \\
$\mathrm{H}_{2} \mathrm{NNHPh} \mathrm{5}_{2}$ & $\mathbf{6 a - c}$ & $50-100$ & $1-6$ & $84-94$ \\
$\mathrm{H}_{2} \mathrm{NNHPh} \mathrm{5}_{2}$ & $\mathbf{7 a - c}$ and $\mathbf{8 a - b}$ & $150-200$ & 6 & $88-93$ \\
$\mathrm{H}_{2} \mathrm{NNHCH}_{2} \mathrm{CH}_{2} \mathrm{OH} \mathbf{9}$ & $\mathbf{1 0 a - c}$ and 11b-c & 50 & $1-6$ & $66-74$ \\
\hline
\end{tabular}

a Yields of isolated products.

There is an intense discussion in the literature about solvent effects in reactions performed with $\mathrm{MW}, 5$ and it has been established that some solvents are more efficient than others in transferring the MW energy absorbed in heat. This information is furnished by a mathematical coefficient called the loss tangent $(\tan \delta$ ) and the higher this coefficient is, the faster the temperature increases. ${ }^{5}$ On the other hand, it has been demonstrated that for some microwave reactions, the solvent-free condition is the best condition, resulting in better yields and higher regioselectivity when 
compared with the reaction using solvents. ${ }^{6}$ In this case, the MW absorption irradiation should be limited only to reactive species. In this context, the performance of cyclocondensation reactions presented in this study using MW in the presence of a solvent is very important.

The reaction of enone $\mathbf{1 b}$ was performed with each hydrazine $(\mathbf{2}, \mathbf{5}$ or $\mathbf{9})$ in the presence of methanol. Hydrazine $\mathbf{5}$ was also reacted with enone $\mathbf{1 c}$. The choice of methanol as solvent was based on two experimental factors: $(i)$ methanol is the solvent generally employed in cyclocondensation reactions; $;^{28}$ (ii) methanol possesses one of the greatest values for $\tan \delta(0.941)$ among the organic solvents, thus the transfer of MW energy in heat is considered more efficient. The reactions between enones (1b and $\mathbf{1 c})$ and hydrazines (2,5 and 9) were performed in $\mathrm{MeOH}(1 \mathrm{~mL})$ at the same molar ratio (1 mmol enone: $1.2 \mathrm{mmol}$ hydrazine), temperatures and reaction times as the reaction performed under solvent-free conditions. In all cases, the presence of $\mathrm{MeOH}$ as solvent resulted in decreased yields. These results are depicted in Table 2. Products of all reactions were obtained in better yields under solvent-free conditions than in the presence of $\mathrm{MeOH}$. In the last case, for products 10a and 11a, the reduction in yields in the presence of $\mathrm{MeOH}$ was smaller than that for other products, however the regioselectivety was unaltered. These results demonstrate the importance of the high efficiency and environmentally benign conditions of solvent-free reactions.

Table 2. Synthesis of 4,5-dihydro- $1 H$-pyrazoles using $\mathrm{MeOH}$ as solvent under microwave irradiation

\begin{tabular}{|c|c|c|c|c|}
\hline Product $(\mathrm{s})^{\mathrm{a}}$ & $\mathrm{T}\left({ }^{\circ} \mathrm{C}\right)$ & time $(\min )$ & Molar ratio & Yield $^{\mathrm{b}}(\%)$ \\
\hline $3 b$ & 100 & 6 & - & 60 \\
\hline $6 \mathbf{b}$ & 50 & 1 & - & 82 \\
\hline $6 c$ & 50 & 6 & - & 78 \\
\hline $10 b: 11 b$ & 50 & 1 & $1: 5$ & 57 \\
\hline
\end{tabular}

${ }^{\mathrm{a}}$ All reactions were performed with $1 \mathrm{mmol}$ enone:1.2 mmol hydrazine in $1 \mathrm{~mL} \mathrm{MeOH} .{ }^{\mathrm{b}}$ Yields of isolated products.

The results of the cyclocondensation reactions to obtain 4,5-dihydro-1 $H$-pyrazoles using MW equipment for synthesis were compared with those obtained by domestic MW oven and with the conventional method (reflux in molecular solvent), as shown in Table 3. The comparison of the reactions performed in MW equipment for synthesis and the reactions performed in domestic MW oven was difficult because of the inaccurate evaluation of reaction conditions such as the presence or the absence of solvent and MW criteria such as temperature and power measurements in domestic MW ovens. However, the comparison established in Table 3 demonstrates that, for the reaction of enones 1a-c with methyl hydrazinocarboxylate $\mathbf{2}$, though the reaction times and yields were similar, in the domestic MW oven, the reproducibility of these reactions was lower. When comparing the efficiency in obtaining product $\mathbf{3 b}$ in the conventional method and using MW equipment for synthesis, it was observed that the microwave for synthesis furnished the product in better yield, shorter time and with a 'greener' method, due to the absence of solvent.

For reactions of enones 1a-c with phenylhydrazine 5, the reactions in a domestic MW oven were faster (3 min), however the products were formed in the presence of toluene, a toxic and dangerous solvent. In addition, the reaction of enone 1a with $\mathbf{5}$ furnished a mixture of 4,5-dihydro- $1 H$-pyrazole and pyrazole in a molar ratio of 2:1, respectively. Product $\mathbf{6 c}$ was obtained only after 15 min of irradiation, while product $7 \mathbf{c}$ was not observed. Therefore, the reaction of enones 1a-c with $\mathbf{5}$ in MW equipment for synthesis furnished better results in terms of yields, absence of solvent and reaction time (6 min for all compounds) when compared with the reaction performed in a domestic MW oven. Comparing the results obtained by the reactions performed in MW equipment for synthesis and those carried out in conventional methods for products 6a-c, we observed greater efficiency in MW equipment for synthesis, demonstrated by the better yields, shorter reaction time and absence of solvent.

The compounds formed from the reaction of enones 1a-c and 2-hydroxyethylhydrazine 9 described in this paper are novel and their synthesis in domestic MW oven has not yet been reported. In conventional conditions, the reaction of 4,4,4-trifluoro-1-pyridin-2-yl-butane-1,3-dione with 2-hydroxyethylhydrazine at $0{ }^{\circ} \mathrm{C}$ for $7 \mathrm{~h}$ gave 4,5 -dihydro$1 \mathrm{H}$-pyrazole and at $25^{\circ} \mathrm{C}$ for $15 \mathrm{~h}$ furnished a mixture of 4,5-dihydro- $1 H$-pyrazoles and pyrazoles..$^{29}$

It is worthy to note that in many cyclocondensation reactions performed in $\mathrm{MW}$ or using a conventional method, ${ }^{26}$ it was necessary to use pyridine and/or toxic solvents such as toluene and the regioselectivity of the reaction was unsatisfactory. In this context, the novel method developed by our research group is very satisfactory in terms of both chemical and environmental aspects.

\section{Conclusion}

In conclusion, in the present study, we presented a new, simple and 'greener' method for the formation of 4,5-dihydro- $1 H$-pyrazoles and dehydrated pyrazoles, using microwave irradiation under solvent-free conditions.

In the reaction of $\mathbf{1 a - c}$ with $\mathbf{2}$ and $\mathbf{5}$, the 4,5-diidro- $1 \mathrm{H}$ pirazóis was obtained in mild conditions and the pyrazole was formed at more drastic temperature conditions. In 
Table 3. 4,5-Dihydro-1H-pyrazoles obtained using both MW equipment for synthesis, domestic MW oven and conventional method

\begin{tabular}{|c|c|c|c|c|c|c|c|c|c|c|c|}
\hline \multirow[b]{2}{*}{ Prod. } & \multicolumn{2}{|c|}{$\begin{array}{l}\text { MW for synthesis under } \\
\text { solvent-free conditions }\end{array}$} & \multirow[b]{2}{*}{$\begin{array}{l}\text { Yield }^{c} \\
(\%)\end{array}$} & \multicolumn{4}{|c|}{ Domestic MW oven ${ }^{\mathrm{a}}$} & \multicolumn{4}{|c|}{ Conventional method ${ }^{\mathrm{b}}$} \\
\hline & $\begin{array}{l}\text { time } \\
(\mathrm{min})\end{array}$ & $\begin{array}{c}\mathrm{T} \\
\left({ }^{\circ} \mathrm{C}\right)\end{array}$ & & Solv. & $\begin{array}{l}\text { time } \\
(\mathrm{min})\end{array}$ & $\begin{array}{c}\mathrm{T} \\
\left({ }^{\circ} \mathrm{C}\right)\end{array}$ & Yield $(\%)$ & Solv. & $\begin{array}{l}\text { time } \\
(\mathrm{h})\end{array}$ & $\begin{array}{c}\mathrm{T} \\
\left({ }^{\circ} \mathrm{C}\right)\end{array}$ & Yield $^{\mathrm{c}}(\%)$ \\
\hline $3 \mathbf{a}$ & 8 & 100 & 73 & - & 6 & 80 & 82 & $-{ }^{\mathrm{e}}$ & - & - & - \\
\hline $3 \mathbf{b}$ & 6 & 100 & 90 & - & 6 & 80 & 85 & $\mathrm{EtOH}$ & 5 & 78 & 62 \\
\hline $3 \mathbf{c}$ & 6 & 50 & 82 & - & 6 & 80 & 93 & $-{ }^{e}$ & - & - & - \\
\hline $6 \mathbf{a}$ & 6 & 100 & 84 & Toluene & 3 & 86 & $77^{\mathrm{d}}$ & $\mathrm{EtOH}$ & 4 & 78 & 73 \\
\hline $6 b$ & 1 & 50 & 95 & Toluene & 3 & 86 & 91 & $\mathrm{EtOH}$ & 4 & 78 & 70 \\
\hline $6 c$ & 6 & 50 & 94 & Toluene & 15 & 104 & 80 & $-{ }^{e}$ & - & - & - \\
\hline
\end{tabular}

References used for domestic MW oven data: Compounds 3a-b, ${ }^{30}$ compounds $\mathbf{6 a}-\mathbf{c} .{ }^{26}{ }^{\mathrm{b}}$ References used for conventional method: Compounds $\mathbf{6 a - b} .{ }^{25}$ ${ }^{c}$ Yields of isolated products. ${ }^{\mathrm{d}}$ Mixture of 4,5-dihydro- $1 \mathrm{H}$-pyrazole and pyrazole in a molar ratio of 2:1, respectively. ${ }^{\mathrm{e}}$ This reaction has not yet been reported in the literature.

the reaction of 1a-c with $\mathbf{9}$, the 4,5-dihydro- $1 H$-pyrazole was not isolated, and in all reaction conditions evaluated, the dehydrated pyrazoles were obtained. In addition, we verified that while the conventional thermal heating method gives only moderate yields of the expected cyclocondensation reaction products, microwave irradiation under solvent-free conditions leads to the same products with a drastic reduction of reaction time and improved yields. The use of MW equipment for synthesis allowed for safe and reproducible reaction conditions.

\section{Experimental}

\section{General}

The experiments were performed in MW Discover CEM using both modes of operation (with and without simultaneous cooling). ${ }^{1} \mathrm{H}$ and ${ }^{13} \mathrm{C}$ NMR spectra were recorded on a Bruker DPX $400\left({ }^{1} \mathrm{H}\right.$ at $400.13 \mathrm{MHz}$ and ${ }^{13} \mathrm{C}$ at $100.62 \mathrm{MHz}$ ) in $\mathrm{CDCl}_{3} / \mathrm{TMS}$ solutions at $298 \mathrm{~K}$ and chemical shifts $(\delta)$ are givem in ppm. Mass spectra were registered in a HP 5973 MSD connected to a HP 6890 GC and interfaced by a Pentium PC. The GC was equipped with a split-splitless injector, cross-linked to a HP-5 capillary column ( $30 \mathrm{~m}, 0.32 \mathrm{~mm}$ i.d.), and helium was used as the carrier gas. The melting points were measured using a Microquímica MQAPF 301. The melting points were not corrected.

General procedure for the cyclocondensation reaction of enones with hydrazines (Schemes 1-3)

A $10 \mathrm{~mL}$ microwave vessel equipped with a standard cap (vessel commercially furnished by CEM Discover) was filled with $1 \mathrm{mmol}$ of enone 1a-c and $1.2 \mathrm{mmol}$ of hydrazines $\mathbf{2 , 5}, \mathbf{9}$. After the vessel was sealed, the sample was irradiated for the times and temperatures indicated in Schemes 1-3, which was plotted in Synergies Version
3.5.9 software applying the power of $200 \mathrm{~W}$ as the maximum level of irradiation and a maximum level of internal vessel pressure of $250 \mathrm{psi}$. The irradiation power was in the range of $1-95 \mathrm{~W}$ for reactions at $50-100{ }^{\circ} \mathrm{C}$, with simultaneous cooling and 30-190 W for reaction at 150-200 ${ }^{\circ} \mathrm{C}$, without simultaneous cooling. The reaction mixture was subsequently cooled to $50^{\circ} \mathrm{C}$ by compressed air. The reaction mixture was isolated with chloroform $(5 \mathrm{~mL})$ and washed with water $(3 \times 5 \mathrm{~mL})$. The chloroform was evaporated under vacuum (reduced pressure) and the products were obtained in a pure form without further purification. The data report of some reactions furnished by the software are depicted in Supplementary Information.

1-Carboxymethyl-5-trifluoromethyl-5-hydroxy-4,5dihydro-1H-pyrazole (3a): $\mathrm{mp} 78-81{ }^{\circ} \mathrm{C} ;{ }^{1} \mathrm{H} \mathrm{NMR}\left(\mathrm{CDCl}_{3}\right)$ $\delta 3.17$ ( d, 1H, $\left.{ }^{2} J 19 \mathrm{~Hz}, \mathrm{H} 4 \mathrm{~b}\right), 3.36$ (d, 1H, $\left.{ }^{2} J 19 \mathrm{~Hz}, \mathrm{H} 4 \mathrm{a}\right)$, 3.89 (s, $\left.3 \mathrm{H}, \mathrm{OCH}_{3}\right), 6.95$ (s, $\left.\mathrm{H}, \mathrm{H} 3\right) ;{ }^{13} \mathrm{C} \mathrm{NMR}\left(\mathrm{CDCl}_{3}\right) \delta 44.8$ (C4), $53.5\left(\mathrm{OCH}_{3}\right), 89.3\left(\mathrm{q},{ }^{2} J 33 \mathrm{~Hz}, \mathrm{C} 5\right), 122.8\left(\mathrm{q},{ }^{1} J 268 \mathrm{~Hz}\right.$, $\mathrm{CF}_{3}$ ), $144.3(\mathrm{C} 3), 153.5(\mathrm{C}=\mathrm{O})$; GC/MS (EI, $70 \mathrm{eV}$ ) m/z 212 $\left(\mathrm{M}^{+}, 8 \%\right), 181$ (5), 143 (100), 69 (25).

1-Carboxymethyl-5-trifluoromethyl-5-hydroxy-3-methyl4,5-dihydro-1 H-pyrazole $(3 b)$ : $\mathrm{mp} 55-56{ }^{\circ} \mathrm{C} ;{ }^{1} \mathrm{HNMR}\left(\mathrm{CDCl}_{3}\right)$ $\delta 2.07$ (t, 3H, $\left.\mathrm{CH}_{3}\right), 3.13$ (d, 1H, $\left.{ }^{2} J 19 \mathrm{~Hz}, \mathrm{H} 4 \mathrm{a}\right), 3.38$ (d, 1H, $\left.{ }^{2} J 19 \mathrm{~Hz}, \mathrm{H} 4 \mathrm{~b}\right), 3.88\left(\mathrm{~s}, 3 \mathrm{H}, \mathrm{OCH}_{3}\right) ;{ }^{13} \mathrm{C} \mathrm{NMR}\left(\mathrm{CDCl}_{3}\right) \delta$ $15.1\left(\mathrm{CH}_{3}\right), 44.8(\mathrm{C} 4), 53.3\left(\mathrm{OCH}_{3}\right), 90.6\left(\mathrm{q},{ }^{2} \mathrm{~J} 34 \mathrm{~Hz}, \mathrm{C} 5\right)$, $122.9\left(\mathrm{q},{ }^{1} \mathrm{~J} 286 \mathrm{~Hz}, \mathrm{CF}_{3}\right), 153.4(\mathrm{C} 3), 153.9$ (C=O); GC/MS (EI, $70 \mathrm{eV}) \mathrm{m} / \mathrm{z} 226\left(\mathrm{M}^{+}, 23 \%\right), 195$ (5), 157 (100), 126 (5), 98 (10), 81 (18).

1-Carboxymethyl-5-trifluoromethyl-5-hydroxy-3-phenyl4,5-dihydro-1H-pyrazole (3c): mp 153-155 ${ }^{\circ} \mathrm{C}$; ${ }^{1} \mathrm{H}$ NMR $\left(\mathrm{CDCl}_{3}\right) \delta 3.55\left(\mathrm{~d}, 1 \mathrm{H},{ }^{2} \mathrm{~J} 18 \mathrm{~Hz}, \mathrm{H} 4 \mathrm{a}\right), 3,69\left(\mathrm{~d}, 1 \mathrm{H},{ }^{2} \mathrm{~J} 18 \mathrm{~Hz}\right.$, H4b), 3.94 (s, 3H, $\mathrm{OCH}_{3}$ ), 7.43-7.45 (m, 3H, Ph), 7.69-7.73 
(m, 2H, Ph); ${ }^{13} \mathrm{C} \mathrm{NMR}\left(\mathrm{CDCl}_{3}\right) \delta 43.3(\mathrm{C} 4), 53.8\left(\mathrm{OCH}_{3}\right)$, 91.6 (q, $\left.{ }^{2} J 34 \mathrm{~Hz}, \mathrm{C} 5\right), 123.5$ (q, $\left.{ }^{1} J 286 \mathrm{~Hz}, \mathrm{CF}_{3}\right), 130.9$, 129.7, 128.7, $126.6(\mathrm{Ph}), 152.9(\mathrm{C} 3), 158.2(\mathrm{C}=\mathrm{O})$; GC/MS (EI, $70 \mathrm{eV}) \mathrm{m} / \mathrm{z}, 288\left(\mathrm{M}^{+}, 85 \%\right), 257$ (2), 229 (2), 219 (100).

5-Trifluoromethyl-1H-pyrazole (4a): Oil; ${ }^{1} \mathrm{H}$ NMR $\left(\mathrm{CDCl}_{3}\right) \delta 6.60\left(\mathrm{~d}, 1 \mathrm{H},{ }^{3} \mathrm{~J} 2 \mathrm{~Hz}, \mathrm{H} 4\right), 7.86\left(\mathrm{~d}, 1 \mathrm{H},{ }^{3} \mathrm{~J} 2 \mathrm{~Hz}, \mathrm{H} 3\right)$, 13.57 (s, $1 \mathrm{H}, \mathrm{NH}) ;{ }^{13} \mathrm{C} \mathrm{NMR}\left(\mathrm{CDCl}_{3}\right) \delta 103.2(\mathrm{C} 4), 122.1$ (q, $\left.{ }^{1} J 267 \mathrm{~Hz}, \mathrm{CF}_{3}\right), 130.5(\mathrm{C} 3), 141.3$ (q, $\left.{ }^{2} J 36 \mathrm{~Hz}, \mathrm{C} 5\right)$; GC/MS (EI, $70 \mathrm{eV}$ ) $\mathrm{m} / \mathrm{z} 136\left(\mathrm{M}^{+}, 100 \%\right), 117$ (49), 69 (65).

5-Trifluoromethyl-3-methyl-1H-pyrazole (4b): $\mathrm{mp}$ 84-85 ${ }^{\circ} \mathrm{C} ;{ }^{1} \mathrm{H}$ NMR $\left(\mathrm{CDCl}_{3}\right) \delta 2.30\left(\mathrm{~s}, 3 \mathrm{H}, \mathrm{CH}_{3}\right), 6.40$ (s, $1 \mathrm{H}, \mathrm{H} 4), 13.29(\mathrm{~s}, 1 \mathrm{H}, \mathrm{NH}) ;{ }^{13} \mathrm{C} \mathrm{NMR}\left(\mathrm{CDCl}_{3}\right) \delta 10.1\left(\mathrm{CH}_{3}\right)$, 102.1 (C4), 122.0 (q, ${ }^{1} J 267 \mathrm{~Hz}, \mathrm{CF}_{3}$ ), 140.6 (C3), 141.2 (q, $\left.{ }^{2} \mathrm{~J} 36 \mathrm{~Hz}, \mathrm{C} 5\right)$; GC/MS (EI, $\left.70 \mathrm{eV}\right) \mathrm{m} / \mathrm{z}, 150\left(\mathrm{M}^{+}, 100 \%\right)$, 131(17), 81 (18).

5-Trifluoromethyl-3-phenyl-1H-pyrazole (4c): Oil; ${ }^{1} \mathrm{H}$ NMR $\left(\mathrm{CDCl}_{3}\right) \delta 6.80$ (s, 1H, H4), 7.26-7.59 (m, 5H, $\mathrm{Ph}) ;{ }^{13} \mathrm{C}$ NMR $\left(\mathrm{CDCl}_{3}\right) \delta 100.9(\mathrm{C} 4), 125.6,127.9,129.1$, $129.3(\mathrm{Ph}), 121.1$ (q, $\left.{ }^{1} J 268 \mathrm{~Hz}, \mathrm{CF}_{3}\right), 143.5\left(\mathrm{q},{ }^{2} J 38 \mathrm{~Hz}, \mathrm{C} 5\right)$, 145.1 (C3); GC/MS (EI, $70 \mathrm{eV}) \mathrm{m} / 2,212\left(\mathrm{M}^{+}, 100 \%\right), 193$ (9), 143 (25), 77 (27).

5-Trifluoromethyl-1,3-diphenyl-1H-pyrazole (7c): $\mathrm{mp}$ 53,7-55, ${ }^{\circ} \mathrm{C}$; ${ }^{1} \mathrm{H}$ NMR $\left(\mathrm{CDCl}_{3}\right) \delta 7.11$ (s, $\left.1 \mathrm{H}, \mathrm{H} 4\right), 7.3-7.88$ $(\mathrm{m}, 10 \mathrm{H}, 2 \mathrm{Ph}) ;{ }^{13} \mathrm{C} \mathrm{NMR}\left(\mathrm{CDCl}_{3}\right) \delta 106.0(\mathrm{C} 4), 121.1$ (q, $\left.{ }^{1} J 269 \mathrm{~Hz} \mathrm{CF}_{3}\right), 125.6,125.8,128.6,128.7,129.0,129.2$, 131.7, 139.1 (Ph), 133.8 (q, $\left.{ }^{2} \mathrm{~J} 38 \mathrm{~Hz}, \mathrm{C} 5\right), 151.6$ (C3); GC/MS (EI, $70 \mathrm{eV}$ ) m/z $288\left(\mathrm{M}^{+}, 100 \%\right), 219$ (13), 77 (88); Calc. for $\mathrm{C}_{16} \mathrm{H}_{11} \mathrm{~N}_{2} \mathrm{~F}_{3}: \mathrm{C}, 67.00 \% ; \mathrm{H}, 4.26 ; \mathrm{N}, 9.47$. Found: C, $67.01 ; \mathrm{H}, 4.03 ; \mathrm{N}, 9.41$.

3-Trifluoromethyl-1-phenyl-1H-pyrazole (8a): Oil; ${ }^{1} \mathrm{H} \mathrm{NMR}\left(\mathrm{CDCl}_{3}\right) \delta 6.70\left(\mathrm{~d},{ }^{3} \mathrm{~J} 2 \mathrm{~Hz}, 1 \mathrm{H}, \mathrm{H} 4\right), 7.32\left(\mathrm{~d},{ }^{3} \mathrm{~J} 2 \mathrm{~Hz}\right.$, $1 \mathrm{H}, \mathrm{H} 3), 7.41-7.67$ (m, 5H, Ph); ${ }^{13} \mathrm{C} \mathrm{NMR}\left(\mathrm{CDCl}_{3}\right) \delta 105.9$ (C4), 121.2 (q, ${ }^{1} J 269 \mathrm{~Hz}, \mathrm{CF}_{3}$ ), 125.6, 129.0, 129.2, 138.0 (Ph), 139.4 (C5), 143.9 (q, ${ }^{2}$ J 39 Hz, C3); GC/MS (EI, $70 \mathrm{eV}$ ) m/z $212\left(\mathrm{M}^{+}, 100 \%\right), 193$ (15), 143 (17), 77 (72); Calc. for $\mathrm{C}_{10} \mathrm{H}_{7} \mathrm{~N}_{2} \mathrm{~F}_{3}: \mathrm{C}, 56.61 ; \mathrm{H}, 3.33$; N, 13.20. Found: C, 56.43; $\mathrm{H}, 3.58 ; \mathrm{N}, 13.53 \%$.

The spectroscopy data for compounds $\mathbf{6 a - c}, \mathbf{7 a - b}$ and $\mathbf{8 b}$ are present in the references 26 and 27.

5-Trifluoromethyl-1-(2-hydroxyethyl)-1H-pyrazole (10a): Oil; ${ }^{1} \mathrm{H} \mathrm{NMR}\left(\mathrm{CDCl}_{3}\right) \delta 4.08\left(\mathrm{t}, 2 \mathrm{H}, \mathrm{CH}_{2}\right), 4.34$ (t, $\left.2 \mathrm{H}, \mathrm{CH}_{2}\right)$, $6.64(\mathrm{~s}, 1 \mathrm{H}, \mathrm{H} 4), 7.53(\mathrm{~s}, 1 \mathrm{H}, \mathrm{H} 3) ;{ }^{13} \mathrm{C} \mathrm{NMR}\left(\mathrm{CDCl}_{3}\right) \delta$ $52.3\left(\mathrm{CH}_{2}-\mathrm{N}\right), 60.9\left(\mathrm{CH}_{2}-\mathrm{OH}\right), 107.5(\mathrm{C} 4), 120.0\left(\mathrm{q},{ }^{1} \mathrm{~J} 268 \mathrm{~Hz}\right.$, $\mathrm{CF}_{3}$ ), 132.3 (q, $\left.{ }^{2} \mathrm{~J} 39 \mathrm{~Hz}, \mathrm{C} 5\right), 138.7$ (C3); GC/MS (EI, $70 \mathrm{eV}$ ) $\mathrm{m} / \mathrm{z}, 181\left(\mathrm{M}^{+}, 29 \%\right), 149$ (100), 137 (60), 69 (14).
5-Trifluoromethyl-1-(2-hydroxyethyl)-3-methyl-1Hpyrazole (10b): Oil; ${ }^{1} \mathrm{H} \mathrm{NMR}\left(\mathrm{CDCl}_{3}\right) \delta 2.27\left(\mathrm{~s}, 3 \mathrm{H}, \mathrm{CH}_{3}\right)$, $4.03\left(\mathrm{t}, 2 \mathrm{H}, \mathrm{CH}_{2}\right), 4.24\left(\mathrm{t}, 2 \mathrm{H}, \mathrm{CH}_{2}\right), 6.42(\mathrm{~s}, 1 \mathrm{H}, \mathrm{H} 4)$; ${ }^{13} \mathrm{C}$ NMR $\left(\mathrm{CDCl}_{3}\right) \delta 141.0(\mathrm{C} 3),{ }^{\mathrm{a}}(\mathrm{q}, \mathrm{C} 5)$ and ${ }^{\mathrm{a}}\left(\mathrm{CF}_{3}\right), 106.0$ (C4), $61.3\left(\mathrm{CH}_{2}-\mathrm{OH}\right), 52\left(\mathrm{CH}_{2}-\mathrm{N}\right), 13.2\left(\mathrm{CH}_{3}\right)$; GC/MS (EI, $70 \mathrm{eV}) \mathrm{m} / z, 195\left(\mathrm{M}^{+}, 33 \%\right), 177$ (6),163 (100), 151 (32); Calc. for $\mathrm{C}_{7} \mathrm{H}_{9} \mathrm{~N}_{2} \mathrm{~F}_{3} \mathrm{O}: \mathrm{C}, 43.30 ; \mathrm{H}, 4.67 ; \mathrm{N}, 14.43$. Found: C, 43.51; H, 4.49; N, 14.13\%. ${ }^{a}$ Due the low concentration of 1,5-isomer, the signals of $\mathrm{C} 5$ and $\mathrm{CF}_{3}$ were not observed.

5-Trifluoromethyl-1-(2-hydroxyethyl)-3-phenyl-1Hpyrazole (10c): Oil; ${ }^{1} \mathrm{HNMR}\left(\mathrm{CDCl}_{3}\right) \delta 4.11\left(\mathrm{t}, 2 \mathrm{H}, \mathrm{CH}_{2}\right), 4.38$ (t, $\left.2 \mathrm{H}, \mathrm{CH}_{2}\right), 6.93$ (s, 1H, H4), 7,35-7.41 (m, 5H, Ph); ${ }^{13} \mathrm{CNMR}$ $\left(\mathrm{CDCl}_{3}\right) \delta 52.5\left(\mathrm{CH}_{2}-\mathrm{N}\right), 61.1\left(\mathrm{CH}_{2}-\mathrm{OH}\right), 104.3(\mathrm{C} 4), 119.8$ $\left(\mathrm{q},{ }^{1} \mathrm{~J} 268 \mathrm{~Hz}, \mathrm{CF}_{3}\right), 125.6,128.7,128.8,128.5(\mathrm{Ph}), 133.4(\mathrm{q}$, $\left.{ }^{2} J 38 \mathrm{~Hz}, \mathrm{C} 5\right), 150.9$ (C3); GC/MS (EI, 70 eV) $\mathrm{m} / \mathrm{z} 256\left(\mathrm{M}^{+}, 8 \%\right.$ ), 212 (100), 143 (8), 77 (64); Calc. for $\mathrm{C}_{16} \mathrm{H}_{11} \mathrm{~N}_{2} \mathrm{~F}_{3} \mathrm{O}$ : C, 52.25; H, 4.33; N, 10.93. Found: C, 52.59; H, 4.32; N, $10.87 \%$.

3-Trifluoromethyl-1-(2-hydroxyethyl)-1H-pyrazole (11a): Oil; ${ }^{1} \mathrm{H}$ NMR $\left(\mathrm{CDCl}_{3}\right) \delta 4.01\left(\mathrm{t}, 2 \mathrm{H}, \mathrm{CH}_{2}\right), 4.29$ (t, $\left.2 \mathrm{H}, \mathrm{CH}_{2}\right), 6.53$ (s, 1H, H4), 7.53 (s, 1H, H5); ${ }^{13} \mathrm{C} \mathrm{NMR}$ $\left(\mathrm{CDCl}_{3}\right) \delta 54.6\left(\mathrm{CH}_{2}-\mathrm{N}\right), 60.9\left(\mathrm{CH}_{2}-\mathrm{OH}\right), 104.2(\mathrm{C} 4)$, 121.1 (q, ${ }^{1} J 268 \mathrm{~Hz}, \mathrm{CF}_{3}$ ), 131.7 (C5), 142.5 (q, ${ }^{2} \mathrm{~J} 38 \mathrm{~Hz}$, C3); GC/MS (EI, $70 \mathrm{eV}) \mathrm{m} / \mathrm{z} 181\left(\mathrm{M}^{+}, 29 \%\right), 149$ (100), 137 (45), 69 (31); Calc. for $\mathrm{C}_{6} \mathrm{H}_{7} \mathrm{~N}_{2} \mathrm{~F}_{3} \mathrm{O}: \mathrm{C}, 40.01 ; \mathrm{H}, 3.92$; $\mathrm{N}, 15.55$. Found: C, 40.39; H, 4.09; N, 15.83\%.

3-Trifluoromethyl-1-(2-hydroxyethyl)-5-methyl-1Hpyrazole (11b): Oil; ${ }^{1} \mathrm{H} \mathrm{NMR}\left(\mathrm{CDCl}_{3}\right) \delta 2.33\left(\mathrm{~s}, 3 \mathrm{H}, \mathrm{CH}_{3}\right)$, $4.04\left(\mathrm{t}, 2 \mathrm{H}, \mathrm{CH}_{2}\right), 4.15\left(\mathrm{t}, 2 \mathrm{H}, \mathrm{CH}_{2}\right), 6.30(\mathrm{~s}, 1 \mathrm{H}, \mathrm{H} 4)$; ${ }^{13} \mathrm{C} \mathrm{NMR}\left(\mathrm{CDCl}_{3}\right) \delta 11.0\left(\mathrm{CH}_{3}\right), 51.2(\mathrm{C}-\mathrm{N}), 61.2(\mathrm{C}-\mathrm{OH})$, 103.7 (C4), 121.3 (q, $\left.{ }^{1} J_{2} 68 \mathrm{~Hz}, \mathrm{CF}_{3}\right), 141.5$ (C5), 142.0 (q, $\left.{ }^{2} J 38 \mathrm{~Hz}, \mathrm{C} 3\right)$; GC/MS (EI, $\left.70 \mathrm{eV}\right) \mathrm{m} / z, 195\left(\mathrm{M}^{+}, 100 \%\right)$, 177 (16), 163 (79), 151 (62); Calc. for $\mathrm{C}_{7} \mathrm{H}_{9} \mathrm{~N}_{2} \mathrm{~F}_{3} \mathrm{O}$ : C, 43.30 ; $\mathrm{H}, 4.67$; N, 14.43. Found: C, 43.51; H, 4.49; N, 14.13\%.

3-Trifluoromethyl-1-(2-hydroxyethyl)-5-phenyl-1Hpyrazole (11c): Oil; ${ }^{1} \mathrm{H} \mathrm{NMR}\left(\mathrm{CDCl}_{3}\right) \delta 4.03\left(\mathrm{t}, 2 \mathrm{H}, \mathrm{CH}_{2}\right)$, $4.25\left(\mathrm{t}, 2 \mathrm{H}, \mathrm{CH}_{2}\right), 6.57$ (s, 1H, H4), 7,41-7.80 (m, 5H, Ph); ${ }^{13} \mathrm{C}$ NMR $\left(\mathrm{CDCl}_{3}\right) \delta 51.6\left(\mathrm{CH}_{2}-\mathrm{N}\right), 61.2\left(\mathrm{CH}_{2}-\mathrm{OH}\right), 104.3$ (C4), 120.5 (q, $\left.{ }^{1} J 268 \mathrm{~Hz}, \mathrm{CF}_{3}\right), 128.9,129.2,129.3,131.6$ (Ph), 142.0 (q, $\left.{ }^{2} J 38 \mathrm{~Hz}, \mathrm{C} 3\right), 145.9$ (C5); GC/MS (EI, $70 \mathrm{eV}$ ) $\mathrm{m} / \mathrm{z} 256\left(\mathrm{M}^{+}, 49 \%\right), 225$ (100), 103 (10), 77 (98); Calc. for $\mathrm{C}_{16} \mathrm{H}_{11} \mathrm{~N}_{2} \mathrm{~F}_{3} \mathrm{O}: \mathrm{C}, 52.25 ; \mathrm{H}, 4.33$; N, 10.93. Found: C, 52.59; $\mathrm{H}, 4.32 ; \mathrm{N}, 10.87 \%$.

\section{Supplementary Information}

Supplementary Information is available free of charge at http://jbcs.org.br, as PDF file. 


\section{Acknowledgements}

The authors are grateful to Conselho Nacional de Desenvolvimento Científico e Tecnológico (CNPq), Fundação de Amparo à Pesquisa do Estado do Rio Grande do Sul (FAPERGS) and CAPES for financial support and fellowships.

\section{References}

1. Anastas, P. T.; Warner, J. C.; Green Chemistry: Theory and Practice; Oxford Science Publications: New York, 1998; Anastas, P.; Williamson, T.; Green Chemistry, Frontiers in Benign Chemical Synthesis and Processes; Oxford Science Publications: New York, 1998.

2. Clark, J. H.; Green Chem. 1999, $1,1$.

3. Clark, J. H.; Chem. British 1998, 34, 43.

4. Bougrin, K.; Loupy, A.; Soufiaoui, M.; J. Photochem. Photobiol., C 2005, 6, 139; Martins, M. A. P. Frizzo, C. P.; Moreira, D. N.; Buriol, L.; Machado, P.; Chem. Rev. 2009, 109, 4140; Martins, M. A. P. Frizzo, C. P.; Moreira, D. N.; Zanatta, N.; Bonacorso H. G.; Chem. Rev. 2008, 108, 2015.

5. Kappe, C. O.; Dallinger, D.; Mol. Diversity 2009, 13, 71.

6. Kappe, C. O.; Chem. Soc. Rev. 2008, 37, 1127.

7. Loupy, A.; Microwaves in Organic Synthesis, $2^{\text {nd }}$ ed., Wiley-VCH: Weinheim, 2006; Lidström, P.; Tierney, J. P.; Microwave-Assisted Organic Synthesis, Blackwell Publishing: Oxford, 2005.

8. Kappe, C. O.; Angew. Chem., Int. Ed. 2004, 43, 6250; Hayes, B. L.; Aldrichimica Acta 2004, 37, 66; Roberts, B. A.; Strauss, C. R.; Acc. Chem. Res. 2005, 38, 653; Hayes, B. L.; Microwave Synthesis: Chemistry at the Speed of Light, CEM Publishing: Matthews NC, 2002.

9. De La Hoz, A.; Diaz-Ortiz, A.; Moreno, A.; Chem. Soc. Rev. 2005, 34, 164.

10. Kappe, C. O.; Stadler, A.; Microwaves in Organic and Medicinal Chemistry, Wiley-VCH: Weinheim, Germany, 2005.

11. Leadbeater, N. E.; Pillsbury, S. J.; Shanahan, E.; Williams, V. A.; Tetrahedron 2005, 61, 3565; Arvela, R. K.; Leadbeater, N. E.; Org. Lett. 2005, 7, 2101; Jachuck, R. J. J.; Selvaraj, D. K.; Varma, R. S.; Green Chem. 2006, 8, 29; Singh, B. K.; Appukkuttan, P.; Claerhout, S.; Parmar, V. S.; Van der Eycken, E.; Org. Lett. 2006, 8, 1863; Baxendale, I. R.; Griffiths-Jones, C. M.; Ley, S. V.; Tranmer, G. T.; Chem. Eur. J. 2006, 12, 4407.

12. Strauss, C. R.; Trainor, R. W.; Aust. J. Chem. 1995, 48, 1665.

13. Westaway, K. C.; Gedye. R. N.; J. Microwave Power Electromagn. Energy 1995, 30, 219.

14. Loupy, A.; Perreux, L.; Burle, M. L. K.; Moneuse, M.; Pure Appl. Chem. 2001, 73, 161.

15. Shaaban, M. R.; J. Fluorine Chem. 2008, 129, 1156 ; Regnier, T.; Lavastre, O.; Tetrahedron 2006, 62, 155.
16. Saeed, A.; Mumtaz, A.; Chin. Chem. Lett. 2008, 19, 1305; Ju, Y.; Varma, R. S.; Tetrahedron Lett. 2005, 36, 6011.

17. El Ashry, E. S. H.; Ramadan, E.; Kassem, A. A.; Hagar, M. ; Adv. Heterocycl. Chem. 2005, 88, 1; Humphries, P. S.; Finefield, J. M.; Tetrahedron Lett. 2006, 47, 2443.

18. Mulder, R.; Wellinga, K.; Van Daalen, J.; Naturwissenschaften 1975, 62, 531; Elguero, J. In Comprehensive Heterocyclic Chemistry II; Katritzky, A. R.; Rees, C. W.; Scriven, E. F. V., eds.; Elsevier Science: New York, 1996; vol. 3.

19. Taylor, E. C.; Patel, H.; Kumar, H.; Tetrahedron 1992, 48, 8089.

20. Bansal, E.; Srivatsava, V. K.; Kumar, A.; Eur. J. Med. Chem. 2001, 36, 81; Souza, F. R.; Souza, V. T.; Ratzlaff, V.; Borges, L. P.; Oliveira, M. R.; Bonacorso, H. G.; Zanatta, N.; Martins, M. A. P.; Mello, C. F.; Eur. J. Pharmacol. 2002, 451, 141.

21. Milano, J.; Rossato, M. F.; Oliveira, S. M.; Drewes, C.; Machado, P.; Beck, P.; Zanatta, N.; Martins, M. A. P.; Mello, C. F.; Rubin, M. A.; Ferreira, J.; Bonacorso H. G.; Life Sci. 2008, 83, 739; Sauzem, P. D.; Machado, P.; Rubin, M. A.; Sant'Anna, G. S.; Faber, H. B.; de Souza, A. H.; Mello, C. F.; Beck, P.; Burrow, R. A.; Bonacorso, H. G.; Zanatta, N.; Martins M. A. P.; Eur. J. Med. Chem. 2008, 43, 1237.

22. Martins, M. A. P.; Cunico, W.; Pereira, C. M. P.; Flores, A. F. C.; Bonacorso, H. G., Zanatta, N.; Curr. Org. Synth. 2004, 1, 391; Druzhinin, S. V.; Balenkova, E. S.; Nenajdenko, V. G.; Tetrahedron 2007, 63, 7753.

23. Moura, S.; Flores, A. F. C.; Paula, F. R.; Pinto, E.; Machado, P.; Martins, M. A. P.; Lett. Org. Chem. 2008, 5, 91.

24. Martins,M.A.P.; Moreira, D. N.; Frizzo, C.P.; Longhi, K.;Zanatta,N.; Bonacorso, H. G.; J. Braz. Chem. Soc. 2008, 19, 1361.

25. Braibante, M. E. F.; Clar, G.; Martins, M. A. P.; J. Heterocycl. Chem. 1993, 30, 1159.

26. Martins, M. A. P.; Pereira, C. M. P.; Moura, S.; Frizzo, C. P.; Beck, P.; Zanatta, N.; Bonacorso, H. G.; Flores, A. F. C.; J. Heterocycl. Chem. 2007, 44, 1195; Frizzo, C. P.; Moreira, D. N.; Guarda, E. A.; Fiss, G. F.; Marzari, M. R. B.; Zanatta, N.; Bonacorso, H. G.; Martins M. A. P.; Catal. Commun. 2009, 10, 1153.

27. Sloop, J. C.; Bumgardner, C. L.; Loehle, W. D.; J. Fluorine Chem. 2002, 118, 135; Diab, J.; Laurent, A.; Le Dréan, I.; J. Fluorine Chem. 1997, 84, 145.

28. Katritzky, A. R.; Rees, C. W., eds.; Comprehensive Heterocyclic Chemistry, Pergamon Press: New York, 1984, vol. 1-8; Katritzky, A. R.; Ress, C. W.; Scriven, E. F. V.; eds.; Comprehensive Heterocyclic Chemistry II, Pergamon: Oxford, 1996, vol. 1-9.

29. Montoya, V.; Pons, J.; García-Antón, J.; Solananessas, X.; FontBardia, M.; Ros, J.; J. Fluorine Chem. 2007, 128, 1007.

30. Beck, P. H.; PhD Thesis, Universidade Federal de Santa Maria, Brazil, 2007.

Received: October 7, 2009

Web Release Date: March 4, 2010 


\section{Pyrazole Synthesis under Microwave Irradiation and Solvent-free Conditions}

\section{Lilian Buriol, Clarissa P. Frizzo, Mara R. B. Marzari, Dayse N. Moreira,} Liziê D. T. Prola, Nilo Zanatta, Helio G. Bonacorso and Marcos A. P. Martins *

Núcleo de Química de Heterociclos, Departamento de Química, Universidade Federal de Santa Maria, 97105-900 Santa Maria-RS, Brazil

Data obtained microwave (MW) equipment

\section{Method Parameters}

Name: $m 300871$

Type: Dynamic

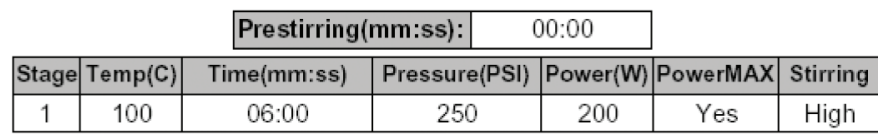

Graphs
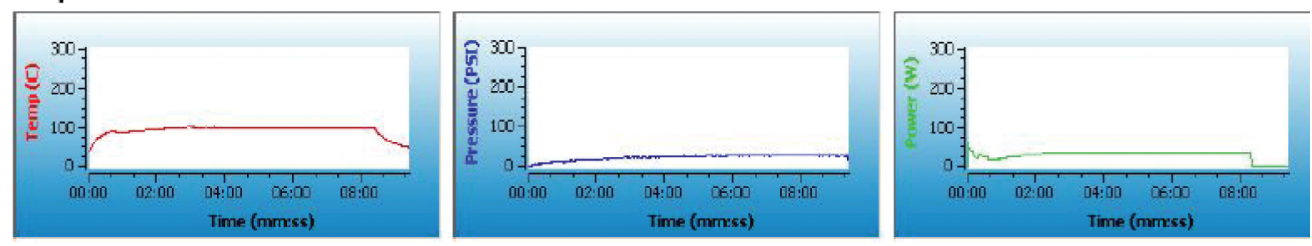

\section{Method Summary}

Reaction started:

Temperature setpoint reached:

Reaction cooling started:

Cooling/Reaction ended:

24/10/2008 15:16:08

24/10/2008 15:18:40

24/10/2008 15:24:41

$24 / 10 / 200815: 25: 46$

Reaction Completed Successfully!

Maximum temperature:

Maximum pressure:

Time to obtain setpoint

Time at setpoint

Time cooling:
$101 \mathrm{C}$

$29 \mathrm{PSI}$

02:32 mm:ss

06:01 mm:ss

01:05 mm:ss

Figure S1. Reaction condition (MW parameters to obtainment of product 6a).

*e-mail: mmartins@base.ufsm.br 


\section{Method Parameters}

Name: m3o 0922

Type: Dynamic

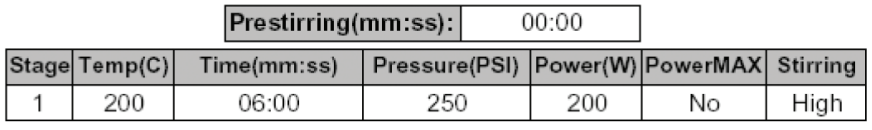

\section{Graphs}
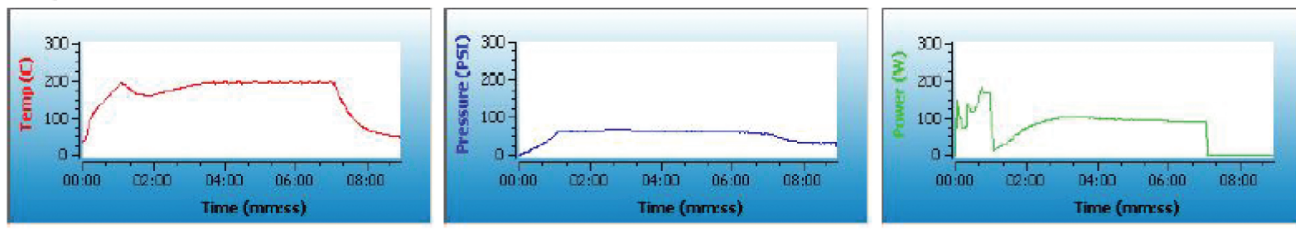

\section{Method Summary}

Reaction started:

Temperature setpoint reached:

Reaction cooling started:

Cooling/Reaction ended:

$31 / 10 / 200814: 33: 48$

$31 / 10 / 200814: 35: 02$

$31 / 10 / 200814: 41: 03$

Reaction Completed Successfully!

Maximum temperature:

Maximum pressure:

Time to obtain setpoint:

Time at setpoint:

$31 / 10 / 200814: 42: 54$

Time cooling:

$$
\begin{aligned}
& 200 \mathrm{C} \\
& 70 \text { PSI } \\
& \text { 01:14 mm:ss } \\
& 06: 01 \mathrm{~mm}: \mathrm{ss}
\end{aligned}
$$

$01.51 \mathrm{~mm}: \mathrm{ss}$

Figure S2. Reaction condition (MW parameters to obtainment of product 7a and $\mathbf{8 a}$ ).

\section{Method Parameters}

\begin{tabular}{|c|c|c|c|c|c|c|}
\hline & & \multicolumn{2}{|c|}{ Prestirring(mm:ss): } & $00: 00$ & & \\
\hline Stage & Temp(C) & Time(mm:ss) & Pressure(PSI) & Power(W) & PowerMAX & Stirring \\
\hline 1 & 50 & $01: 00$ & 250 & 200 & Yes & High \\
\hline
\end{tabular}

Name: $\mathrm{m} 300782$

Type: Dynamic

\section{Graphs}
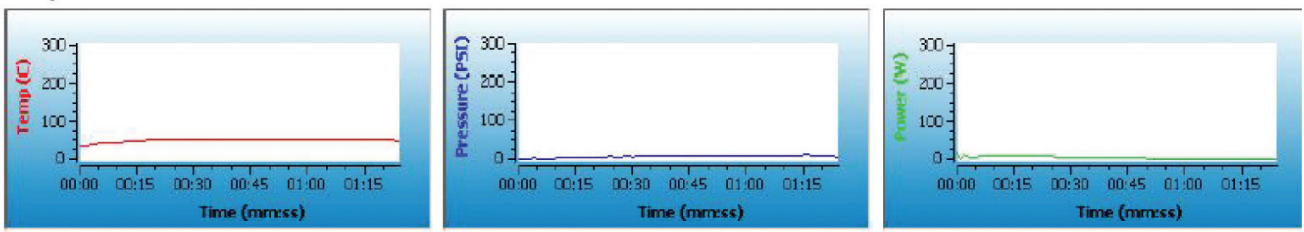

\section{Method Summary}

Reaction started:

Temperature setpoint reached:

Reaction cooling started:

17/10/2008 14:46:16

$17 / 10 / 200814: 46: 44$

$17 / 10 / 200814: 47: 44$

Cooling/Reaction ended:

$17 / 10 / 200814: 47: 52$

Reaction Completed Successfully!

Maximum temperature:

Maximum pressure:

$53 \mathrm{C}$

Time to obtain setpoint:

$11 \mathrm{PSI}$

00:28 mm:ss

Time at setpoint:

01:00 mm:ss

Time cooling

00:08 mm:ss

Figure S3. Reaction condition (MW parameters to obtainment of product $\mathbf{6 b}$ ). 


\section{Method Parameters}

Name: m3a 1754

Type: Dynamic \begin{tabular}{|l|l|l|l|l}
\hline Prestirring(mm:ss): & $00: 00$ \\
\hline
\end{tabular}

\begin{tabular}{|c|c|c|c|c|c|c|}
\hline Stage & Temp(C) & Time(mm:ss) & Pressure(PSI) & Power(W) & PowerMAX & Stirring \\
\hline
\end{tabular}

\section{Graphs}
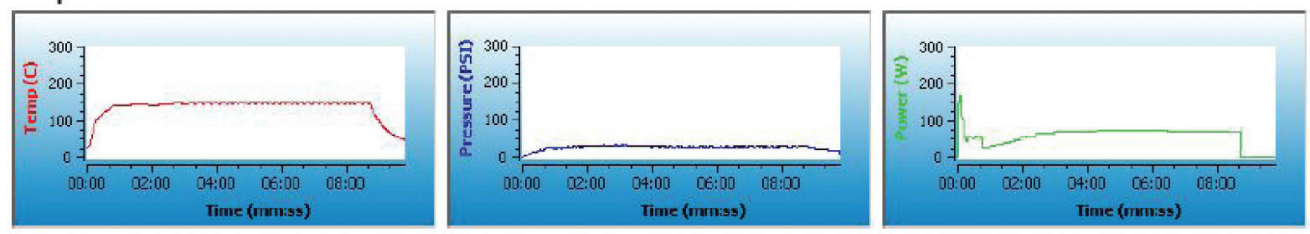

\section{Method Summary}

Reaction started:

Temperature setpoint reached:

Reaction cooling started:

30/04/2009 09:17:04

30/04/2009 09:19:58

$30 / 04 / 200909: 25: 59$

Cooling/Reaction ended:

30/04/2009 09:27:02

Reaction Completed Successfully!

Maximum temperature

$151 \mathrm{C}$

Maximum pressure:

$35 \mathrm{PSI}$

Time to obtain setpoint

Time at setpoint:

02.54 mmiss

06:01 mm:ss

Time cooling:

Figure S4. Reaction condition (MW parameters for obtainment of product $\mathbf{7 b}$ and $\mathbf{8 b}$ ).

\section{Method Parameters}

Name: m3n 0992

Type: Dynamic \begin{tabular}{|l|l}
\hline Prestirring(mm:ss): & $00: 00$
\end{tabular}

\begin{tabular}{|c|c|c|c|c|c|c|}
\hline Stage & Temp(C) & Time(mm:ss) & Pressure(PSI) & Power(W) & PowerMAX & Stirring \\
\hline 1 & 50 & $06: 00$ & 250 & 200 & Yes & High \\
\hline
\end{tabular}

\section{Graphs}
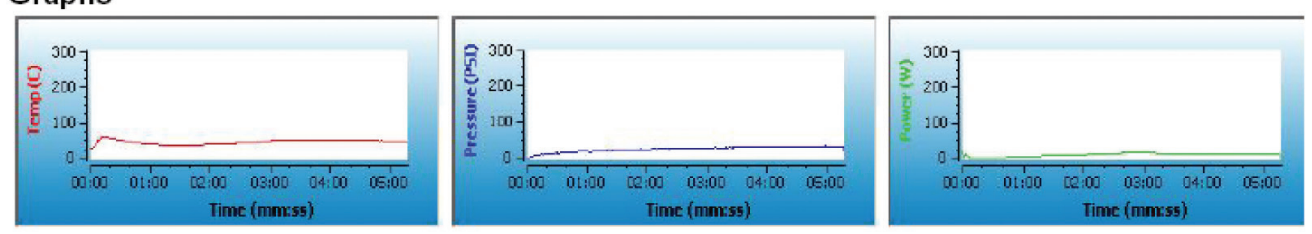

\section{Method Summary}

Reaction started:

Temperature setpoint reached:

Reaction cooling started

Cooling/Reaction ended:

Reaction Completed Successfully!

Maximum temperature

Maximum pressure:

Time to obtain setpoint:

Time at setpoint:

Time cooling:
07/11/2008 09:18:12

07/11/2008 09:18:31

07/11/2008 09:24:32

$07 / 11 / 200809: 24: 33$

$59 \mathrm{C}$

$34 \mathrm{PSI}$

00:19 mm:ss

06:01 mm:ss

00:01 mm:ss

Figure S5. Reaction condition (MW parameters for obtainment of product $\mathbf{6 c}$ ). 


\section{Method Parameters}

Name: m3n 0993

Type: Dynamic

Prestirring(mm:ss):
\begin{tabular}{|c|c|c|c|c|c|c|}
\hline Stage & Temp(C) & Time(mm:ss) & Pressure(PSI) & Power(W) & PowerMAX & Stirring \\
\hline 1 & 150 & $06: 00$ & 250 & 200 & No & High \\
\hline
\end{tabular}

\section{Graphs}
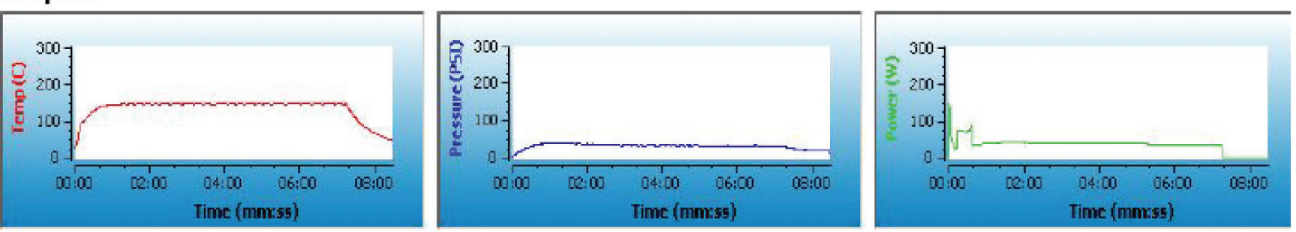

\section{Method Summary}

Reaction started:

Temperature setpoint reached:

Reaction cooling started:

Cooling/Reaction ended:

07/11/2008 09:25:42

$07 / 11 / 200809: 27: 30$

$07 / 11 / 200809: 33: 30$

07/11/2008 09:34:45

Reaction Completed Successfully!

Maximum temperature:

Maximum pressure:

$151 \mathrm{C}$

$39 \mathrm{PSI}$

Time to obtain setpoint:

$01: 48 \mathrm{~mm}$ 'ss

Time at setpoint:

06:00 mm:ss

Time cooling:

01:15 mm:ss

Figure S6. Reaction condition (MW parameters for obtainment of product 7c).

\section{Method Parameters}

Name: m3J 1201

Type: Dynamic

\begin{tabular}{|c|c|c|c|c|c|c|}
\hline & & \multicolumn{2}{|c|}{ Prestirring(mm:ss): } & $00: 00$ & & \\
\hline Stage & Temp(C) & Time(mm:ss) & Pressure(PSI) & Power(W) & PowerMAX & Stirring \\
\hline 1 & 50 & 01:00 & 250 & 200 & Yes & High \\
\hline
\end{tabular}

\section{Graphs}
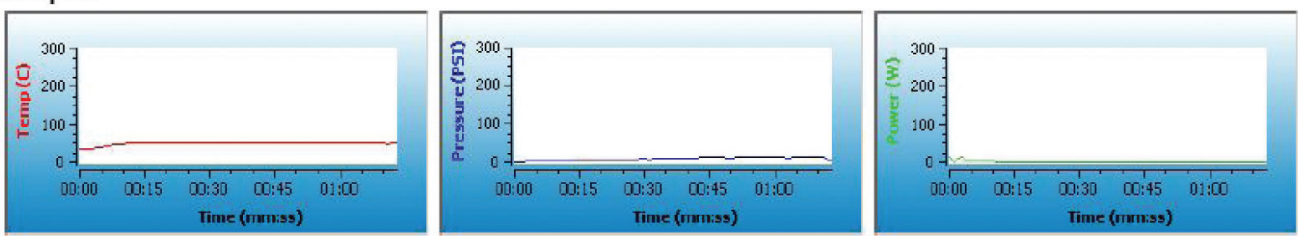

\section{Method Summary}

Reaction started:

Temperature setpoint reached:

Reaction cooling started:

08/01/2009 09:40:17

08/01/2009 09:40:38

08/01/2009 09:41:39

Cooling/Reaction ended

Reaction Completed Successfully!

Maximum temperature:

Maximum pressure:

$52 \mathrm{C}$

Time to obtain setpoint:

$17 \mathrm{PS}$

00:21 mm:ss

01:01 mm:ss

Time at setpoint

00:03 mm:ss

Figure S7. Reaction condition (MW parameters for obtainment of product $\mathbf{6 b}$ in the presence of $\mathrm{MeOH}$ ). 


\section{Method Parameters}

Name: M3J 1211

\begin{tabular}{|l|l}
\hline Prestirring(mm:ss): & $00: 00$
\end{tabular}

Type: Dynamic

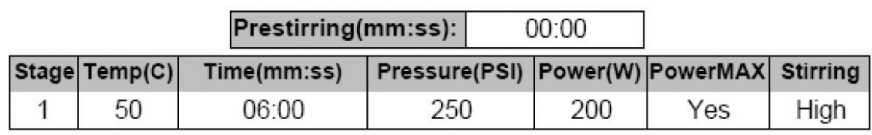

\section{Graphs}
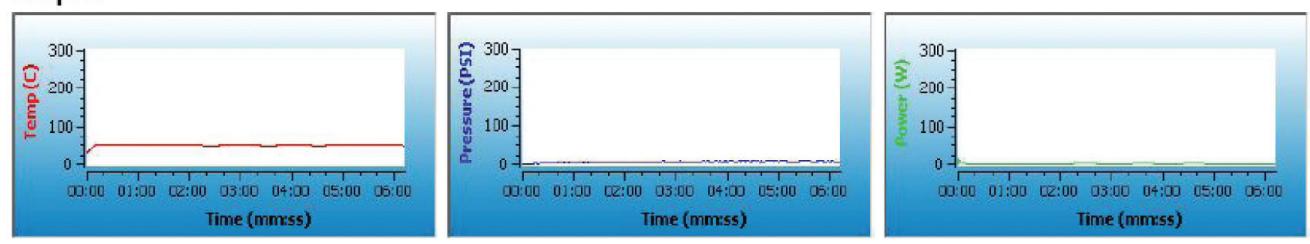

\section{Method Summary}

Reaction started

Temperature setpoint reached:

Reaction cooling started:

08/01/2009 09:42:59

08/01/2009 09:43:20

08/01/2009 09:49:21

Cooling/Reaction ended

08/01/2009 09:49:24

Reaction Completed Successfully!

Maximum temperature:

Maximum pressure:

Time to obtain setpoint

Time at setpoint:

$53 \mathrm{C}$

$13 \mathrm{PSI}$

00.21 mmss

06:01 mm:ss

Time cooling

00:03 mm:ss

Figure S8. Reaction condition (MW parameters for obtainment of product $\mathbf{6 c}$ in the presence of $\mathrm{MeOH}$ ). 